\title{
O EXCESSO DE ADAPTAÇĀO DAS CARTAS ESTADUAIS À CONSTITUIÇÃO DE 1967
}

\author{
RAYMUNDO FAORO \\ (Procurador do Estado da Guanabara.)
}

Ao longo da tradição republicana, vigora o princípio de que o poder constituinte dos Estados-membros thes é outorgado diretamente pelo povo, tal como o poder constituinte conferido à União. O Decreto n. ${ }^{\circ} 1$, de 15 de novembro de 1889, escrito no calor da vitória de um ideal longamente perseguido, proclamou que os Estados, "no exercício de sua legítima soberania", decretariam a sua Constituição. A fórmula consagrada nos documentos fundamentais, lavrados no curso de tempestuosa história, pôsto que menos enfática, conservou-se fiel à diretriz revolucionária: cada Estado reger-se-á pela Constituição que adotar, respeitados os princípios da Constituição Federal (1891, art. 63; 1930, art. 4. ${ }^{\circ}$; 1934, art. 7. ${ }^{\circ}$ ।; 1937, art. 21,$1 ; 1946$, art. 18; A.I. n. ${ }^{\circ}$, art. $1 .^{\circ} ; 1967$, art. 13). O elemento essencial da autonomia dos Estados, nos documentos republicanos, situou-se, sempre, no poder de elaborar as suas constituições. O Estado existe como Estado na medida em que se auto-organiza constitucionalmente (J. BRYCE - La République Américane, Paris, 1912, tomo II, pág. 35; CARRÉ DE MALBERG - Teoria Generel del Estado, México, 1948, pág. 160; TEMÍSTOCLES CAVALCANTI - Revista de Direito da Procuradoria Geral, vol. 15, pág. 36).

A existência do Estado condiciona-se à existência da União, dentro da qual se expressam seus podêres, competência e atividade. A República Federativa exige, conceitualmente, a coordenação dos Estados, em união indissolúvel. Coordenação é o contrário de separação e de subordinação, - o poder estatal dos Estados-membros irrompe de suas entranhas, sem derivar-se da unidade política maior (maior, e não superior) (T. MAUNZ - Deutsches Staatsrecht, München, 1963, pág. 171). Dentro da União, como parte dela, os Estados devem obedecer a normas mínimas de homogeneidade (homogeneidade; não - conformidade ou uniformidade) (MANGOLDT e KLEIN 
- Das Bonner Grundgesetz, B. 1, Berlim, 1957, pág. 697). A coordenação e a homogeneidade se corporificam nos princípios constitucionais da União, que limitam o campo da autonomia estadual, demarcando-lhe, no conteúdo e na extensão, os vínculos da sua es. trutura federal. (A determinação, enumerada ou não, dos princípios constitucionais, é uma constante de tôdas as Federações: Estados Unidos, art. IV, seção 4: ..."every State in this Union a Republic Form of Government"...; Alemanha, art. 28: ..."Grundsätzen des republikanischen, demokratischen"... conhecidos na doutrina como os "Normativbestimmungen".) Em virtude da pendência sôbre os Estados de tais normas, que lhes restringem a autonomia, seu poder constituinte não é soberano, submetendo-se às regras de coordenação e homogeneidade impostas pela Constituição Federal. Trata-se de poder constituinte secundário (sem conotá-lo com poder constituinte derivado cuja plenitude, como acentuou o Ministro LUIZ GALLOTTI, com apoio de seus pares, só encontra barreiras nos princípios da Carta Federal (Repr. n. 466 e RMS n. ${ }^{\circ} 9.558$, in, respectivamente, RDA ns. 73, pág. 222, 75, pág. 247). Fora daí, a atividade constituinte é livre, sujeita apenas aos limites por ela própria impostos para reformas subseqüentes. Os Estados dispõem de poder constituinte próprio, autônomo, limitado ùnicamente pelas prescrições constitucionais da União. Esta a doutrina referendada pelo Supremo Tribunal Federal. Do mesmo teor é a lição da Côrte Constitucional alemã: os Estados gozam do poder constituinte que deflui de sua própria condição, obedecidos apenas os princípios constitucionais federais, pressupostos na ordem jurídica local. (Die Länder sind als Glieder des Bundes Staaten mit eigener - wenn auch gegenständlich beschränkter - nicht vom Bund abgeleiteter, sondern von ihm anerkannter staatlicher Hoheitsmacht - Solange ein Land besteht und seine verfassungsmässige Ordnung sich im Rahmen des art. 28 Abs. 1 GG hält, kann der Bund ohne verletzung des im Grundgesetz garantierten bundesstaatlichen Prinzips in seine Verfassungsordnung nicht eingreifen - Entscheidungs des Bundersverfassungsgerichts - 1. Band, Tübingen, 1952, pág. 18.) Qualquer interferência da União nos Estados, fora de tais fronteiras, Ihes fere a autonomia, violando a Constituição Federal.

2. No exercício de seus podêres federais, derivados dos princípios constitucionais, a União tem competência para assegurar a coordenação e a homogeneidade dos Estados-membros. Pode ela restabelecer por influxo central, as regras de convivência comum, das quais se tresmalhem os Estados. Dispõe a União, para essa tarefa, de meios de execução forçada, com os quais constrange o Estado a retornar ao caminho da obediência à Lei Suprema do país. 
Todos os remédios, criados para êsse fim, pressupõem a estrutura federal, dado que no Estado unitário o poder central subordina a unidade local, de modo vertical.

A história constitucional brasileira apresenta impressionante conjunto de expedientes e medidas, destinados a constranger os Estados ao cumprimento de seus deveres de homogeneidade política. Lało sensu, todos os recursos da União se compreendem no conceito da intervenção federal. Há, todavia, modalidades diversas dêsse instituto, que, nas sub-espécies, tem tonalidade específica, de conteúdo diferenciado. Fundamentalmente, duas situações inspiraram e determinaram tratamento diverso: a) os Estados descumpririam os preceitos previstos no art. 10 da Constituição Federal, sofrendo a intervenção decretada pelo Presidente da República, com prazo certo, em regra imposta para auxiliar a um órgão local, perturbado ou tolhido por outro (M. USTERI - Theorie des Bundesstaates, Zurich, 1954, pág. 314); b) os Estados desobedeceriam, nas suas Constituições ou leis, os princípios federais, quer negligenciando o dever de elaborar suas normas básicas, quer, na sua feitura, desviando-se dos mandamentos de cumprimento obrigatório. Recusar-se-iam a se constitucionalizar, por exemplo, depois de certos períodos de colapso democrático, ou se negariam a ajustar suas cartas a novas determinações federais. Em última análise, os Estados, obrigados a emitir declaração escrita de vontade, a omitiriam ou a expressariam imperfeitamente. A intervenção federal não poderia vencer a resistência do constituinte ou do legislador estadual, dado que não dispõe de recursos para determinar manifestação positiva de vontade. $O$ interventor poderia, no máximo, diligenciar na reforma da Constituição Estadual (PAULO DE LACERDA - Princípios de Direito Constitucional Brasileiro, Rio, s/d, vol. II, pág. 92), dado que a êle se não atribuem os podêres de legislar (PONTES DE MIRANDA - Comentários à Const. de 1967, Rio, 1967, vol. I, pág. 263), de criar nova legalidade, devendo limitar-se aos atos de conservação (AURELINO LEAL - Teoria e Prática da Const. Brasileira, Rio, 1925, pág. 94). Para alcançar a inscrição nas Cartas locais ou nas leis estaduais de certo texto, como prestação positiva, o instituto de intervenção federal, no sentido corrente da locução, é insuficiente. Mesmo a dita intervenção reconstrutiva, lançada na doutrina por GONZÁLEZ CALDERÓN (Derecho Constitucional Argentino - Buenos Aires, 1926, Vol. III, pág. 548), constitui mera tentativa de alargar o conteúdo do conceito tradicional, sem inovar, ontològicamente, a espécie. Nas hipóteses mencionadas - desobediência ou descumprimento das normas obrigatórias federais - a União sòmente lograria impor suas determinações se, de qualquer modo, substituísse o poder constituinte ou o 
legislador estadual. Atuaria, então, por conta e em nome do Estado. A prática constitucional brasileira conhece, para sanar a omissão estadual, as seguintes medidas:

A - Os Estados que, até certo prazo, não promulguem suas Constituições, recebem, por outorga do Congresso ou do Senado, a Carta de outro, até que a reformem pelo processo nela previsto (Const. de 1891, Disp. Transit., art. 2. ${ }^{\circ}$; Const. de 1934, Disp. Transit., art. 3. ${ }^{\circ}$, § 6. ; Constituição de 1946, ADCT, art. 1.ㅇ, § 9. ${ }^{\circ}$;

B - As Constituições estaduais adaptar-se-ão (o têrmo vem da Carta de 1891, Disp. Transit., art. $2^{\circ}{ }^{\circ}$ ) às inovações da Carta Federal, sempre que esta sofra alterações de incidência estadual (princípios da União). As determinações constitucionais, ou com fôrça constitucional da União prevêm sanção (incorporação automática) ou não estipulam nenhuma sanção específica. (No último caso, como visto, a intervenção federal pode ser medida insuficiente dado que, por ela, é possível não ser alcançada a reforma constitucional):

a) Emenda Constitucional n. ${ }^{\circ} 4$, de 2/9/62 (Ato Adicional):

"Art. 24 - As Constituições dos Estados adaptar-se-ão ao sistema parlamentar de govêrno, no prazo que a lei fixar..."

b) Emenda Constitucional n. ${ }^{\circ} 13$, de 8/4/65:

"Art. 3. - Caberá às Assembléias Legislativas dispor, nas Constituições Estaduais, sôbre as eleições municipais, para tornar obrigatórias as seguintes normas:...."

c) Ato Institucional n. ${ }^{\circ}$ 2, de 27/10/65:

"Art. 32

Parágrafo único - Para os fins dêste artigo, as assembléias emendarão as respectivas Constituições, no prazo de sessenta dias, findo o qual aquelas normas passarão, no que couber, a vigorar automàticamente nos Estados".

d) Ato Complementar n. ${ }^{\circ} 24$, de 18/11/66:

"Art. 3. ${ }^{\circ}$ - As Constituições Estaduais deverão adapłar-se, até 31 de dezembro de 1966, ao cumprimento da Emenda Constitucional n. ${ }^{\circ} 18 \ldots$. 
e) Constituição de 1967:

"Art. 188 - Os Estados reformarão suas Constituições dentro em sessenta dias, para adaptá-las, no que couber, às normas desta Constituição, as quais, findo êsse prazo, considerar-se-ão incorporadas automàticamente às cartas estaduais".

3. Com a incorporação automática (Ato Institucional n. 2 e art. 188 da Constituição de 1967) ou com a outorga, pelo Congresso ou Senado, da Carta de um Estado ao Estado omisso (Constituições de 1891, 1934 e 1946) o constituinte federal teria dado significativo passo para resolver o problema, cheio de dificuldades, de eferivar a sanção contra procedimento rebelde do Estado, com execução in narura. Se não prevista a sanção, qual seria ela?

A intervenção federal, contesta PONTES DE MIRANDA (Comentários à Constifuição de 1946, Rio, 1946, Tomo VIII, pág. 64). Êste era também o pensamento do projeto encaminhado ao Congresso Nacional, no art. 179 (depois o art. 188 da Constituição de 1967): "Os Estados, dentro de sessenta dias, adaptarão as suas Constituições ao disposto nesta Constituição; caso contrário, será decretada a intervenção federal para êsse fim". A intervenção, todavia, poderia suspender ou negar vigência a um texto constitucional estadual, mas não teria a energia suficiente para exigir prestação consistente em manifestação de vontade. Proposta pelo interventor a reforma constitucional, a Assembléia Legislativa poderia recusá-la, sem que, com isso, pudesse sofrer qualquer coerção direta. A essa perplexidade poderia chegar o interventor federal, imobilizado na sua atividade pelos limites intrínsecos do instrumento a êle confiado. Històricamente, esta foi a situação com que se defrontou a União Norte-Americana, após a Guerra de 1860-65, vencidos os Estados insurgentes, porém fundamente comprometidos, em seus Estatutos básicos, com a política escravagista. O "Reconstruction Act", de 1867, convocou convençc̃es constitucionais nos Estados, que deveriam elaborar suas Cartas e submetê-las à aprovação do Congresso. Enquanto isso, os Estados ficariam privados de representação nacional, só a readquirindo após a aceitação da Emenda 14, excluídos das eleições todos os que houvessem participado, ao lado do Sul, na Guerra Civil (Encyclopedia Britannica - "United States of America"). Admitiu-se, para fundamentar tais medidas, que os Estados, com a revolta, haviam regredido à condição de territórios (Encyclop. of the Social Sciences - verb. Sumner, Charles). A doutrina, pôsto que não referendada pela Suprema Côrie, dado seu conteúdo meramente político (Texas v. White, 1869), constitui importante contribuição ao direito das 
federações. Na verdade, porém, as medidas decretadas pelo Congresso americano poderiam ser frustradas pela Convenção Constituinte local, convocada pelo interventor, se se negasse ela a editar as regras exigidas pela União. As coerções indiretas (suspensão de representação no Congresso, ocupação militar) sòmente serviriam para forçar nova estrutura de poder, mas não conseguiriam, se permanecesse a resistência, a emissão de nôvo texto. Êsse resultado só seria possível com a suspensão da autonomia estadual (com decesso para a categoria de território), substituído o poder constituinte local por atividade da União. Uma hipótese e outra adaptação sancionada ou não - levaria, no fundo, a uma única saída: à outorga de preceitos constitucionais. Apenas o caminho seria diferente: incorporação automática ou incorporação por meio de órgão alheio à atividade constitucional do Estado. "O Estado perde sua posição de Estado; torna-se talvez apenas provisòriamente - corpo administrativo autônomo da União. Enquanto durar essa situação existe uma subordinação do Estado (melhor: antigo Estado), à União". (Das betroffene Glied verliert seine Gliedstellung; es wird - vielleicht nur vorübergehend - Selbstverwaltungkörper des Bundes. Solange dieser Zustand andauert, besteht dann eine grundsätliche Subordination des "Gliedes" (besser: ehemaliger Glied) unter den Bund" M. USTERI, ob. cit., pág. 314). O Estado retomaria sua posição constitucional logo que cessasse a medida executiva, com seu cumprimento. O Congresso Nacional ou a Constituição Federal - ao editar normas para o Estado ou ao lhe ditar a incorporação automática não exercem o poder constituinte estadual, senão que o substituiriam, como "instrumento, órgão constitucional transitório" (PONTES DE MIRANDA - Coms. à Const. de 1946, vol. IV, pág. 244). O colapso do poder determina o adormecimento do próprio Estado, até que se complete o transplante, em virtude de identidade entre autonomia estadual e Constituição.

A incorporação automática é, em conseqüência, expediente técnico, engendrado, hàbilmente, para substituir, transitòriamente, o poder constituinte local inerte, omisso ou rebelde. Por êsse meio indolor, evita-se que o Congresso edite normas constitucionais estaduais, degradando o Estado de sua relevância na Federação. Tem a medida, entretanto, o mesmo conteúdo da outorga provisória de uma Constituição de um Estado a outro, por ato do Congresso (1946: $A D C T$, art. 11, $\$ 9 .{ }^{\circ}$ ), ou do imperativo que manda Constituições locais se adaptarem a um texto federal, sem sanção explícita (Emenda Constitucional n. ${ }^{\circ}$, de 2/9/62, art. 24). De um modo ou outro, a sanção é a mesma, qualquer que seja o caminho percorrido para chegar a ela. 
Cria-se, dessa forma, coação específica contra o Estado. Se não concluída a tarefa adaptatória da Carta Federal dentro em sessenta dias se exaure seu poder constituinte. As normas se incorporam automàticamente, por ficção, como se estivessem escritas pelo próprio legislador constituinte. A coerção indireta se converte em execução in natura, direta. Êsse círculo só foi descrito diante de um preceito constitucional imanente: o legislador federal ou estadual não tem o dever de legislar, mesmo quando a Constituição the exija a prestação (... the provision (da Constituição) may be in its nature mandatory to the legislature to enact the needful legislation, though back of is there lies no authority to enforce the command" T. COOLEY - A Treatise on the Constitutional Limitations, Boston, 1903, pág. 119). Sòmente medidas concretas (e não normas) podem ser impostas, quer heterônomamente, quer dentro da mesma unidade, ao cumprimento de um órgão (H. KRÜGER - Allgemeine Staastslehre, Stuttgart, 1964, pág. 768; PETER LERCHE - Das Bundesverfassungsegericht und die Verfassungsdirektiven - Archiv des öffentlichen Rechts, vol. 90, pág. 341. Suscita êste autor o instituto do substitưo processual para a realização, por órgão diverso, da atividade legislativa ou constitucional). Para superar tal obstáculo, criou-se a incorporação ficta, na mesma linha da aprovação tácita das leis, prevista no Ato Institucional n. ${ }^{\circ}$ 1. Em ambas as hipóteses, depois de certo prazo, dá-se por exaurido o poder de legislar, tida a declaração de vontade como enunciada.

4. A Constituição de 1967 alargou o número dos princípios consîitucionais de respeito obrigatório pelos Estados (art. 13). Tentou, ao lado dos princípios estabelecidos, arrolar os princípios enumerados, restringindo sensivelmente a esfera de autonomia estadual, dentro da qual se exerce livremente seu poder constituinte, de caráter originário. De outro lado, as Cartas locais, na mesma linha dos Atos Institucionais ns. 1 e 2 (art. $1 .^{\circ}$ ), foram mantidas, simultâneamente com a autonomia do Estado. $O$ art. 188, ao aludir à reforma das Constituições, expressamente reconheceu o poder constituinte local e a subsistência das cartas a reformar, como é óbvio. Ao mesmo tempo, porém, como fizeram as Emendas Constitucionais ns. 4 $\left(2 / 9 / 61\right.$, art. 24) e 13 (de 8/4/65, art. $3 .^{\circ}$ ), o Ato Institucional n. ${ }^{\circ} 2$ (art. $3^{\circ}$ ), determinou aos Estados que reformassem suas Constituições, para adaptá-las ao nôvo texto, dentro em sessenta dias, em cujo período não teriam vigor, na órbita local, as disposições a serem incorporadas. A sanção prevista para o descumprimento da norma seria o colapso do poder constituinte estadual, a fim de, de fora, dar os preceitos como escritos. 
Diante do texto do art. 188, inúmeras Representações (art. 114, I, 1, da Carta vigente) deram entrada no Supremo Tribunal Federal, fundadas na tese de que a reforma constitucional, no plano dos Estados, ditada pelo mencionado dispositivo da Carta Federal, deveria limirar-se a editar as normas de adoção obrigatória. Qualquer matéria alheia a êsse fim, não estritamente dêle decorrente, desvinculada do âmbito dos princípios inovadores, seria inconstitucional. Criou-se, desta sorte, a figura do excesso de adaptação, pespegada ao citado artigo, sem exame ou crítica. Os Estados teriam sofrido quebra transitória de sua aưonomia constituinte, limitada ao recebimento das normas da Carta de 1967. Ao lado dos princípios constitucionais da União, previstos na Carta de 1946 e em suas emendas, outro ter-se-ia erguido, com a peculiar energia de condicionar a própria atividade constituinte, ordenando-lhe a seleção de seu trabalho. $O$ art. 188 teria introduzido, fora do poder constituinte estadual, específica função constituinte, à margem daquela que exercem normalmente os Estados. A fonte do poder constituinte do Estado não seria mais, para o caso singular, a reconhecida nos arts. 18 da Constituição de 1946 e 13 da Carta vigente, mas a decorrente apenas do art. 188, em si e por si (a expressão reforma seria abundância ou equívoco). Ainda mais: o preceito, embora de igual teor do constante em documentos anteriores, não se aplicaria às hipóteses pretéritas, para o efeito cauteloso de não tocar em obra já feita, embora passível de nulidade (Emenda Constitucional n. ${ }^{\circ} 4$, até o término do mandato dos Governadores em exercício no dia 2 de setembro de 1961; Ato Institucional n. ${ }^{\circ} 2$, de 27/10/ e 27/12/67).

Desprovida de outros arrimos, a tese abriga flagrantes vícios lógicos e jurídicos. Ela supõe o adormecimento temporário, durante - prazo de adaptação, do poder constituinte estadual. Confundiu a sanção com o preceito. O colapso da autonomia do Estado só terá lugar se, esgotado o prazo de 60 dias, o legislador constituinte estadual não houver completado sua tarefa. $O$ art. 188, ao apelar para a reforma das Cartas dos Estados, contém remissão lógica ao art. 13 (18 na Carta de 1946), que consagra o poder constituinte local. Ao revés de paralisá-lo, o artigo incita-o ao exercício do poder constituinte constituído. Sòmente se se mantivesse inerte, cessaria o poder constituinte, suspendendo-se, todavia, só para a obra adaptativa, que The seria imposta por substituição, sem atingir ou obstar qualquer outra emenda, porventura em curso. O desmaio da atividade constituinte é meramente ficto: nada impediria que, ultrapassado o prazo, a Assembléia Legislativa promulgasse a reforma em andamento. Em 15 de maio (60 dias após 15 de março) entraria em vigor o texto federal; no dia 17 de maio a emenda em curso seria promulgada, 
com a revogação de tôdas as disposições em contrário. É o que decorre do art. 188, apreciado no plano puramente constitucional, sem colori-lo com a lei ordinária ou dispositivos das Cartas Estaduais. Sob a mesma perspectiva, a tese do excesso da adaptação encerra abusivo emprêgo do argumento a contrário.

"Os Estados - reza o art. 188 - reformarão suas Constituições dentro em sessenta dias, para adaptá-las, no que couber, às normas desta Constituição". Ao invés de reconhecer que a reforma das Cartas locais é possível precisamente porque os Estados têm o poder de reger-se por Constituições próprias (art. 13), afirma ela que os Estados só têm competência para a reforma, no prazo indicado. Para a aplicação de tal raciocínio, ter-se-ia de provar o caráter excludente da proposição, dado que a menção de uma hipótese não exclui as demais (CARLOS MAXIMILIANO - Hermenêutica e Aplicação do Direito, P. Alegre, 1925, pág. 259; KARL LARENZ - Metodologia de la Ciencia del Derecho, Barcelona, 1966, pág. 307). Sòmente se a reforma das Constituições Estaduais - como premissa maior - abrangesse totalmente, exaustivamente o poder constituinte local, o argumento a contrário teria incidência (EGON SCHNEIDER Logik für Juristen, Berlin v. Frankfurt, 1965, pág. 180). De modo inverso, o que a proposição afirma é que haverá reforma porque o Estado pode-se organizar por sua Constituição: o art. 188 deriva e adquire alma em conseqüência do poder constituinte do Estado (art. 18 da Constituição de 1946 e 13 da Carta de 1967). O argumento a contrário, se ilegitimamente valorizado, importará em cassar, contra a Constituição, o poder constituinte dos Estados.

5. Seria injusto supor, todavia, que o argumento, nuamente apresentado, não se reforçasse de outros pressupostos. Sòmente com a revelação de suas roupagens e adornos, colhidos fora do âmbito da Constituição Federal, ganha êle consistência, côr e ânimo. Encasacado convenientemente, o raciocínio assenta nas seguintes premissas:

- a reforma ordenada pelo art. 188 recebeu do legislador federal processo especial, em desacôrdo com os trâmites previstos nas Constituições Estaduais para suas emendas;

- o processo de reforma da Constituição Estadual deriva de um princípio constitucional da União, que define a iniciativa e fixa o quorum de aprovação, violado pelo legislador federal, ao dotar o constituinte local de meio próprio de emenda, violação, todavia, posteriormente legitimada pela Carta de 1967. A exceção do legislador federal só vale nos estritos limites por êle previstos. 
Houve, dessa maneira, ao lado do processo comum e regular de emenda, outro sistema excepcional e peculiar às circunstâncias de urgente transição.

Caracterizaria o excesso de adaptação uma inconstitucionalidade formal ou prosessual, que "decorre da preterição de formalidades legislativas: 0 ato em foco se acha compreendido na competência do órgão, mas o órgão funcionou em contravenção ao processo estabelecido para o seu funcionamento" (FRANCISCO CAMPOS - Direito Constitucional, Rio, 1956, vol. II, págs. 116 e 117; CARLOS MAXIMILIANO - Comentários à Constituição Brasileira de 1946, Rio, 1948, vol. II, pág. 362).

6. Pära que a inconstitucionalidade formal ou processual se caracterize é necessário fixar o processo ou as formalidades que a reforma constitucional deve obedecer, legitimando sua atividade. A Constituição Federal tem normas específicas que delimitam e prescrevem $\circ$ processo de emendas (1967: arts. 50 a 55; 1946: art. 217 e parágrafos). As Cartas Estaduais, igualmente, traçam as formalidades sob as quais se deve pautar o legislador constituinte, para assegurar a validade do ato reformatório. A Constituição da Guanabara de 27 de março de 1961 consagrou a seguinte regra:

"Art. 8. - Esta Constituição poderá ser total ou parcialmente modificada, mediante proposta da têrça parte, no mínimo, dos membros da Assembléia.

$\S 1 .^{\circ}$ A proposta dar-se-á por aceita se aprovada em duas discussões, por maioria absoluta, em dois anos consecutivos, ou se obtiver o voto de dois têrços dos membros da Assembléia, em duas discussões, na mesma sessão legislativa".

O texto reproduz, com a diferença do número mínimo de deputados para a proposta (quarta parte), o que dispunha o art. 217 da Carta de 1946, a cuja sombra se formou [merece ser observado que as Constituições Estaduais, salvo no que se referem ao quorum mínimo da maioria absoluta, não guardaram fidelidade ao modêlo federal, exceto as da Bahia (art. 26), Minas Gerais (art. 150), Piauí (art. 172) e Rio Grande do Sul (art. 249)].

De acôrdo com os dispositivos mencionados ter-se-ia, provisòriamente, para efeito de construir o raciocínio: a Carta Estadual da Guanabara, na reforma obrigatória imposta pelo art. 188 da Constituição Federal ou no uso do poder constituinte previsto no art. 13 (18 da Carta de 1946), deveria aprovar qualquer nôvo dispositivo 
constitucional por maioria absoluta, em dois anos consecutivos, ou miediante o voto de dois têrços dos membros da Assembléia, em duas discussões, na mesma sessão legislativa. Fora daí, estaria vulnerada a Constituição local, maculada a emenda de inconstitucionalidade formal ou processual. Ora, argumentar-se-ia, - e assim se completa a figura do excesso de adaptação: o legislador constituinte estadual violou a Carta local, adotando processo extravagante de emenda, sob o estímulo do Decreto-lei n. ${ }^{\circ} 216$, de 27 de fevereiro de 1967, editado com o fim de proporcionar aos Estados meio expedito, rápido e eficiente de levar a cabo tarefa imposta no art. 188 da Carta Magna, mediante a adoção das "normas e prazos estabelecidos no Ato Institucional n. ${ }^{\circ} 4$, de 7 de dezembro de 1966, relativamente ao processo de elaboração da Constituição Federal" (art. 2. " parágrafo único). Permitiu-se, contra o disposto na Constituição Estadual, a iniciativa, para o projeto, do Chefe do Poder Executivo, e sua aprovação por maioria absoluta, em dois turnos, na mesma sessão legislativa. Ao reformar a Carta local, o legislador constituinte a ofendeu, servil a um diploma federal (que seria, no conteúdo, manifestamente inconstitucional, duvidosamente validado pelo art. 173, III, da Constituição de 1967, já promulgada na dała do Decreto-lei n. $\left.{ }^{\circ} 216\right)$.

7. A tese do excesso de adaptação fundar-se-ia, portanto, na desobediência à Carta local (processo de emenda) pelo legislador constituinte do Estado. Com base nesse raciocínio, o Supremo Tribunal Federal foi inundado por grande número de representações (art. 114, I, 1, da Constituição federal), endossadas pelo Procurador-Geral da República, argüindo a "inconstitucionalidade de lei ou ato normativo... estadual". Nelas não se apontou nenhum princípio constitucional federal ofendido, de modo a caracterizar a inconstitucionalidade material ou intrínseca do ato, sob o aspecto do confronto com a Carta Magna, senão apenas a desobediência do processo reformatório, estabelecido nas Constituições Esładuais. O processo de emenda destas deveria ser obrigatòriamente seguido, opina PONTES DE MIRANDA, no comentário ao art. 24 da Emenda Constitucional n. ${ }^{\circ}$, de 1961 (Ato Adicional), que determinava às Constituições dos Estados adaptar-se ao sistema parlamentar, observando - jurista que "na lei complementar de nenhum modo se podem dispensar as regras jurídicas insertas nas Constituições estaduais para as suas emendas" (Coms. à Const. de 1946, Rio, 1962, tomo VIII, pág. 188; nos Coms. à Const. de 1967, São Paulo, 1968, tomo VI, pág. 457 - repete a observação, sem explicitá-la, como o fizera anteriormente). 
Sob tal fundamento - conflito entre a emenda e o processo da Carta local que a legitima - a Representação é absolutamente inadmissível. A Representação versa sôbre ato normativo ou lei federal ou estadual que vulnera a Constituição Federal, nos claríssimos têrmos dos seus art. $11, \S 1 .^{\circ}$, c, e 141, I, 1, bem como do art. $1 .^{\circ}$ da Lei 4.337 , de $1 .^{\circ}$ de junho de 1964 (A jurisprudência do S.T.F. é uniforme e conclusiva, neste sentido: Repr. n. ${ }^{\circ} 289$, in Rev. Trim. de Jurispr., vol. 6, pág. 71; Repr. n. ${ }^{\circ} 308$, id. ibid., vol. 5, pág. 181; Repr. n. ${ }^{\circ}$ 269, ibid., vol. 6, pág. 163; Repr. n. ${ }^{\circ} 600$, ibid., vol. 33, pág. 662; depois da Emenda Constitucional n. ${ }^{\circ} 16$, de 26 de novembro de 1965 e da vigência da Constituição de 1967; Repr. n. ${ }^{\circ}$ 700, ibid., vol. 41, pág. 571): "A inconstitucionalidade da lei questionada só procederia, se fôsse a Constituição do Estado declarada incompatível, nesse ponto, com a Constituição Federal" (Min. VICTOR NUNES LEAL;) Repr. n.ํ 709, ibid., vol. 42, pág. 279).

A representação contra violação de normas das Cartas Estaduais, prevista na Emenda Constitucional n. ${ }^{\circ}$ 16, de 26 de novembro de 1965, não logrou acolhida na vigente Constituição.

8. No processo de reforma das Cartas Estaduais, a Constituição local não estaria vinculada apenas às suas próprias regras, livremente criadas. Prender-se-ia à observância dos princípios constitucionais da União, que Ihe delimitam o campo de aplicação e Ihe traçam os rumos. A ofensa do procedimento de emenda da Carta Estadual importaria, portanto, em violação a uma norma constitucional federal. A questão, até a vigência do regime de 1967, estaria aberta ao debate, pois sòmente em virtude do art. 13, III, da atual Carta do Brasil a matéria deixou de estar sujeita a dúvidas. Na realidade, o mencionado preceito determinou aos Estados que respeitem, dentre outros princípios, o processo legislativo da União, o qual compreende expressamente a elaboração de emendas à Constituição (art. 49,50 a 52). Êste é, entretanto, um dos casos de adaptação obrigatória, empreendida no período de sessenta dias (art. 188), que só vale para os Estados após incorporado às suas Constituições, por meio de reforma ou automàticamente. Entre a vigência da Carta de 1967 e a vigência do preceito na Constituição Estadual, segundo dispõe o art. 188 daquela, há uma vacatio legis, como, ao apreciar dispositivo de igual teor, inserto no Ato Institucional n. ${ }^{\circ}$, observou - Ministro VICTOR NUNES LEAL (Rev. Trim. de Jurispr. - vol. 41, pág. 576). Por conseqüência - como acentuado -, no processo de adaptação, os Estados estavam sob o domínio do direito anterior Carta de 1946 e suas alterações (observe-se, desde logo, que a novidade, dotar os Esłados de igual processo legislativo da União - ar- 
gumenta no sentido de que, antes disso, as unidades federadas estavam em esfera livre da normatividade federal).

A tese da adaptação excessiva se enriquece com um problema prévio: o processo de reforma da Constituição Estadual tem seu conteúdo fixado em algum princípio constitucional da União, que o Estado deve obedecer? No caso afirmativo, a Representação pode ser apreciada pelo Supremo Tribunal Federal; no caso negativo, a matéria diz respeito ao direito estadual, alheio àquele remédio processual.

Não é necessário, para o desate da dúvida, o estudo da natureza e amplitude dos princípios constitucionais da União, cláusula que, inscrita no art. 63 da Constituição de 1891, deu lugar a profundas controvérsias, com a tentativa, a todo passo renovada, de enumerá-los, quer doutrinàriamente, quer nas Cartas constitucionais subseqüentes. O debate, aberto por JOÃO BARBALHO (Constituição Fiederal Brasileira - Comentários ao art. 63), não se pacificou sequer na Constituição de 1967, que, além dos princípios esłabelecidos (sem especificação), distinguiu e precisou os princípios enunciados (art. 13).

a) A doutrina orientou-se no sentido de que o processo legislativo e de emenda ou reforma das Cartas estaduais não está compreendido nos princípios constitucionais da União. No âmbito dêstes se incluiria apenas "a faculdade de emendar e reformar a constituição adotada" (J. BARBALHO - ob. e loc. citados), ou "a possibilidade da reforma constitucional e a competência do poder legislativo para decretá-la" (ERNESTO LEME - A intervenção federal nos Estados, 2. ${ }^{a}$ ed., São Paulo, 1930, págs. 108, 143 e 144). Em obra editada em 1926, especialmente dedicada ao tema em estudo, SAMPAIO DÓRIA adotava o mesmo entendimento: "... o princípio da revisibilidade (não, observe-se, - o processo de revisão) está na Constituição, e a êste princípio não podem furtar-se os Estados nas Constitiuções que adotem" (A. DE SAMPAIO DÓRIA - Princípios Constitucionais, São Paulo, 1926, pág. 110). A lição de RUI esclarece, ainda na atualidade, os fundamentos e a extensão da matéria. ... "os princípios constitucionais da União" escreve - "dividem as instituições consagradas na Constituição, em três classes, profundamente distintas". "A primeira é a das instituições federais, que os Estados podem livremente imitar, ou não, nas suas Constituições e nas suas leis" (sistema bicameral, seleção da magistratura, ec.). Os princípios constitucionais da União se encontram em outras duas classes: a) "a das instituições, ou disposições que, estabelecidas no organismo da União, são igualmente indeclináveis na 
organização constitucional dos Estados" (os três podêres; eletividade e a temporariedade do Legislativo e do Judiciário; garantias da Magistratura, etc.); b) ... "instituições ou disposições que, consagradas em benefício da União, com o caráter de privatividade, ou, pela sua própria natureza e substância, essencialmente privativas da União, por isso mesmo não podem ter equivalentes ou análogas nas Constituições dos Estados" (competência exclusiva para decretar certos impostos; competência privativa do Congresso, etc.).

Especificamente para o problema em exame, opinava:

"A divisão do poder público nos três ramos: Legislativo, Executivo e Judiciário, sem a qual não pode estar segura a liberdade, e antes corre os maiores perigos, bem como a faculdade de emendar e de reformar a constituição adotada, entram como elemento fundamental em tôda a organização política tendente a estabelecer um govêrno liberal e democrático, - são garantias supremas, cuja ausência fraudaria o regime estatuído. E, pois, devem considerar-se como cláusulas indeclináveis das Constituições estaduais".

"O Poder Legislativo é uma das matérias que compõem nesta divisão das institiuções constitucionais, a segunda categoria, aquela em que "os princípios constituticionais da União" adscrevem os Estados, não ao dever negativo da abstenção, mas às obrigações ativas da imitação, reprodução e colaboração".

"Uma série numerosa de preceitos dispõem, na Constituição Federal, sôbre o Poder Legislativo, estatuindo a sua composição bicameral .... as regras fundamentais do processo deliberativo na elaboração das leis .........."

"Cada uma dessas disposições representa uma instifuição constîtucional da União . . . . . . . . . . . ."

"Mas, como não pertencem ao número das instituições fundamentais, das que tecem a estrutura orgânica da União, das que the presidem as funções vitais .... não entram na classe dos seus princípios constitucionais ....."

"Aos Estados, pois, assiste a liberdade mais ampla de, nesses pontos, divergirem, como divergido têm, segundo 
os seus interêsses ou opiniões, do modêlo que lhes oferece a Consłituição de 24 de fevereiro".

(Coment. à Const. Brasileira, São Paulo, 1934, vol. V, págs. 7 a 16).

Em síntese: o princípio constitucional da União impõe aos Estados a faculdade de emendar e reformar a Carta e a existência do Poder Legislativo. O processo legislativo pode ser elaborado pelos Estados com a "liberdade mais ampla". O advento das Cartas da Segunda República (1934, 1937 e 1946) não inspira diretriz diversa ou discordante. Ao contrário as Constituições de 1891 (Disp. Trans. art. 2. ${ }^{\circ}$ ), 1934 (Disp. Trans., art. 3. ${ }^{\circ}, \S 6 .^{\circ}$ ), 1946 (ADCT - art. 11, $\left.\S 9 .^{\circ}\right)$ dispuseram expressamente que o processo de emenda das Cartas Estaduais seria aquêle nelas determinado. Admitiu PONTES DE MIRANDA, no seu estudo acêrca da Constituição de 1946, que os princípios constitucionais não impedem que as Cartas Estaduais consagrem o referendum, instrumento não previsto no processo legislativo e de emenda constitucional no texto de 1946. Doutrina, coerente e na mesma linha das opiniões acima confrontadas:

"Em suma: é preciso que haja Podêres Legislativo, Judiciário e Executivo em corpos. Fora daí, o referendo é permitido. Inclusive como uma instância. Assim, só se exige que haja Assembléia Legislativa, Câmaras Municipais, Governadores e Prefeitos, sem que se vede: a) atribuir-se a iniciativa, ou a deliberação final, ou atribuirem-se a iniciativa e a deliberação final de certas leis, inclusive das emendas constitucionais, ao povo, .............."

(Coms. à Const. de 1946, vol. I, págs. 431, 432).

RAUL MACHADO HORTA, fiel à mesma doutrina, louva a Constituição da Bahia, de 2 de agôsto de 1947, por se haver recusado a ser simples cópia da Carta de 1946. Acolheu ela o instituto do referendum para as emendas constitucionais, se a Assembléia condicionasse sua vigência, pelo voto de dois têrços, à decisão popular ( $A$ Autonomia do Estado-Membro no Direito Constitucional Brasileiro, B. Horizonte, 1964, pág. 232).

O Supremo Tribunal Federal, na única oportunidade, parece, em que apreciou o problema, decidiu que "as Constituições dos Estados... não são obrigadas a adotar o art. 90 da Constituição Federal" (de 1891) (Em 5 de julho de 1919 - in J. A. MENDONÇA DE AZEVEDO - A Constituição Federal Interpretada pelo Supremo Tribunal Federal, Rio, 1925, págs. 291 a 296). 
O exame das Constituições Estaduais, promulgadas em decorrência da ordem institucional de 1946, demonstra que o constituinte local não se sentiu constrangido a acatar o modêlo federal. Muitas não aceitaram a maioria dos dois têrços (Alagoas, art. 156; Amazonas, art. 135; Ceará, art. 174; Espírito Santo, art. 74; Mato Grosso, art. 139; Pará, art. 128; Paraná, art. 166; São Paulo, art. 136; e Sergipe, art. 208); a da Bahia consagrou o referendum (art. 26); as do Ceará (art. 174) e Piauí (art. 172) distinguiram entre a emenda e revisão, com processos próprios. Quase todos os Estados adotaram número diverso do previsto na Carta de 1946 para a iniciativa da emenda.

Os doutôres, o Supremo Tribunal e os constituintes estaduais, concordes, coligam-se no entendimento de que o processo de emenda constitucional não é princípio constitucional da União. Princípio constitucional será a possibilidade (faculdade e competência do Estado) da reforma constiłucional e a competência do Poder Legislativo para decretá-la. (A Emenda de 1926 adotou o princípio expressamente.) Parece-nos, todavia, que, no enunciado da regra, está implícito que a reforma constitucional do Estado deve obedecer a quorum diverso do previsto para a lei ordinária, de modo que esta não altera a Constituição - a fim de assegurar a diferente modificabilidade da lei e da Constituição. (No mesmo sentido: PAULO M. DE LACERDA Princ. de Dir. Const. Bras., vol. Il, pág. 101.) A Constituição só poderá ser emendada, no mínimo, por maioria absoluta, dado que é princípio constitucional a supremacia, no âmbito interno da União e do Estado, da norma constitucional sôbre a lei, como decorrência das normas inscritas nos arts. $8 .^{\circ}$, parágrafo único, 18 e 200 do Texto de 1946 e arts. 11, $\S 9 .^{\circ}$ e 12 do ADCT. (O problema - subordinação das leis ordinárias à Constituição - foi lembrado na Constituinte de 1946, sem merecer consagração, por estar implícito nos princípios constitucionais da União. O então constituinte HERMES LIMA observou que os Estados não estão obrigados ao cumprimento apenas dos princípios enumerados. In JOSÉ DUARTE - A Constituição Brasileira de 1946, Rio, 1947, págs. 426 e 433.)

O processo da reforma da Constituição Estadual não é, portanto, princípio constitucional da União. O princípio tem outro conteúdo (inconfundível com o processo), limitado ao seguinte enunciado: possibilidade de reforma constitucional (pela forma e rito que adotar), competência do Poder Legislativo para decretá-la, com quorum diverso do previsto para a lei ordinária. A Constituição de 1946, sob cujo amparo se processou a adaptação prevista no art. 188 da Carta de 1967, afirmou a regra expressamente: a Constituição Estadual, 
porventura imposta ao Estado omisso no dever de criar seu próprio estatuto fundamental, seria reformada "pelo processo nela determinado" (ADCT - art. 11, § 9..$^{\circ}$.

b) As duas teses apreciadas - desobediência, por parte do legislador constituinte estadual, do processo de emenda da Carta local e a não decorrência do processo de reforma dos princípios constitucionais da União - conduzem ao afastamento preliminar da Representação, que só cuida de infringência da Carta Federal. Se, todavia, - admita-se para argumentar - o legislador constituinte estadual estiver vinculado às normas federais do processo de reforma constitucional, a Representação deve ser conhecida.

Admita-se que a Assembléia Legislativa, ao adotar regras próprias de reforma constitucional, exerceu podêres que extravasam do princípio da forma republicana representativa. Para argumentar, conceda-se que, diversos o quorum e a iniciativa da emenda local, houve afronta às regras de emenda da Carta da União ( $O$ Poder Legislativo teria ganho maior densidade que o correspondente Poder Legislativo da União). Com isso, dois princípios, ou um e outro forma republicana representativa e independência e harmonia dos podêres -, estariam comprometidos. Para efeito de dotar a objeção de pêso, não se leve em conta que os intérpretes da Constituição consideravam tais regras como escritas ainda na Carta de 1891 (J. BARBALHO - ob. e com. cits.) (apenas melhor explicitadas nos textos constitucionais, a partir de 1926).

O legislador constituinte estadual sòmente poderia adaptar a Carta local ao texto federal, de acôrdo com os cânones prescritos na Lei Maior da União. Fora daí, haveria excesso, com ofensa direta à Constituição Estadual que se vai reformar, em conflito que percutiria na Constituição Federal. A iniciativa, número de discussões, as maiorias, em uma ou duas sessões legislativas, a promulgação - todos êsses passos deveriam ser atentamente observados, com ânimo servil, pelo legislador constituinte estadual. Ora, a tarefa reformatória das Constituições estaduais, empreendida em obediência ao art. 188 da Carta de 1967, não se pautou pelas normas necessàriamente derivadas da ordem constitucional, senão pelos preceitos do Decreto-lei $n .^{\circ}$ 216, de 27 de fevereiro de 1967, que ditou às Assembléias Legislativas as normas e prazos do Ato Institucional n. ${ }^{\circ}$, de 7 de dezembro de 1966. [A competência de legislar sob a forma de decretos-leis deu-a ao Presidente da República o Ato Institucional n. ${ }^{\circ} 2$, de 27 de outubro de 1965, em matéria de segurança nacional (art. 31) e no caso do recesso do Congresso Nacional (art. 31), bem como Ato Institucional n. ${ }^{\circ} 4$, de 7 de dezembro de 1966 (art. $\left.9 .^{\circ}, \S 2 .^{\circ}\right)$ ]. Fora 
do período de funcionamento normal do Congresso, expediu o Chefe do Poder Executivo Federal o decreto-lei mencionado, em virtude do qual as Assembléias Legislativas, afrontando o processo de emenda constitucional prescrito na Constituição local com raízes na Carta Maior, se sentiram constrangidas a modificar os textos básicos do Estado. Ora, o Decreto-lei n. ${ }^{\circ} 216$ não poderá ser argüido de inconstitucional - fato que poderia levar à nulidade das deliberações reformatórias das Assembléias Legislativas - em vista da aprovação e validação que the conferiu o art. 173, III, da Constituição de 1967. Mas a confirmação só abrangeria o trabalho de reforma estritamente adaptatório, que fluiu do art. 188 da Carta, expressa e diretamente inspirado no Decreto-lei n. ${ }^{\circ} 216$.

Aí está o raciocínio, com todos os seus elementos: a emenda constitucional recebe seu conteúdo e processo dos princípios constitucionais da União, modificados por um decreto-lei inconstitucional, posteriormente legitimado, de alcance limitado à estrita adaptação à Constituição de 1967. Qualquer dispositivo incorporado às Cartas locais, ao ensejo e pretexto de adaptar, sofreria de inconstitucionalidade (excesso de adaptação).

Os fundamentos e as conseqüências do argumento padecem de graves distorções jurídicas.

Se verdadeira a afirmação de que o processo de reforma das Constituições Estaduais deve obedecer às pautas federais, o padrão a seguir será a norma constitucional da União, à época vigente. Lembre-se, mais uma vez, que o modêlo não será a Constituição de 1967, visto conceder ela aos Estados, no crítico art. 188, o prazo de sessenta dias para a adaptação e um dos objetos desta é exatamente o processo de emenda constitucional. A ênfase que se dá ao argumento, em uma ou outra Representação encaminhada ao Supremo Tribunal Federal, sugere que o quadro típico seria $\circ$ art. 217 da Carta de 1946: iniciativa pela quarta parte dos deputados; maioria absoluta em duas discussões, em duas sessões legislativas ordinárias e consecutivas; duas discussões, na mesma sessão legislativa, por maioria de dois têrços; promulgação pela Mesa. Dado o que dispõe - art. 188 (prazo de sessenta dias), estaria eliminada a maioria absoluta, em duas sessões legislativas: mas o quorum deveria ser de dois têrços. Há nesse ponto de partida, profundo e grosseiro equívoco. A norma padrão não é, no caso, o art. 217 da Carta de 1946, mas o Ato Institucional n. ${ }^{\circ} 2$, de 27 de outubro de 1965, incorporado expressamente à Constituição de 1946 (art. 29), que consagrou as seguintes normas (art. 2. ${ }^{\circ}$ ): iniciativa do chefe do Poder Executivo (já previsto no Ato Institucional n. ${ }^{\circ} 1$, art. $3 .^{\circ}$ ), aprovação da emenda, 
em dois turnos, na mesma sessão legislativa, por maioria absoluta. Que dispôs o Decreto-lei n. ${ }^{\circ} 216$ (inegàvelmente inspirado na doutrina de ser a matéria disciplinada, por meio dos princípios constifucionais, pela União), ao mandar aplicar à adaptação do art. 188 o Ato Institucional n. ${ }^{\circ}$ ? ? resposta é expressa: Iniciativa do Chefe do Poder Executivo; dois turnos (um para o projeto em bloco e outro para as emendas - o que exige, para o exame particularizado, a apreciação dos fatos, se houve ou não emendas: matéria interna corporis), mesma sessão legislativa e maioria absoluta. $O$ Decreto-lei n. ${ }^{\circ} 216$ é absolutamente coerente com o A.I., n. ${ }^{\circ}$. Talvez se lhe possa argüir uma única diferença: enquanto $\circ \mathrm{A} . \mathrm{l}$. n. ${ }^{\circ} 2$ considera aprovada a emenda que, em dois turnos, na mesma sessão legislativa, obtenha maioria absoluta, o Decreto-lei, ao incorporar o processo do A.I. n. ${ }^{\circ} 4$, preenche o conteúdo regimental dos dois turnos. No primeiro turno, o projeto é votado (e discutido) em bloco; no segundo turno, as emendas, depois de sôbre elas emitir parecer a Comissão, serão votadas por maioria absoluta. Poder-se-ia dizer, se o exame interna corporis fôsse possível, que, se o projeto não sofresse emenda, haveria apenas um turno: "a inconstitucionalidade" só se revelaria diante do exame dos documentos, com o confronto entre o texto do projeto e o texto promulgado. (Bastaria a alteração do número dos artigos para comprovar a existência de emendas.) Ocorreria, também, um único turno se a promulgação do projeto decorresse do vencimento do prazo - com o esgotamento dos sessenta dias previsto no art. 188 (conjugado com o rito do Decreto n. ${ }^{\circ} 216$ ).

Essa discordância daria ao Decreto-lei o caráter de norma regimental - invadindo a esfera de competência exclusiva da Assembléia Legislativa -, daí decorreria sua ilegitimidade. No Estado da Guanabara, a observação despe-se de todo o significado, dado que a Assembléia Legislativa editou ato regimental próprio, incorporando, com inovações, o Decreto-lei n. ${ }^{\circ} 216$, suprindo, assim a eventual nulidade (Resolução n. ${ }^{\circ} 253$, de 26 de abril de 1967 - in "Diário da Assembléia Legislativa", de 28 de abril de 1967). Em última análise, o Supremo Tribunal Federal, se apreciar Representação fundada em tal motivo, a desviará, não mais para o estudio da matéria constitucional local, mas para o regimento interno da Assembléia Legislativa.

Sob o ângulo em que foi pôsto - como expressão de um princípio constitucional da União - o Decreto-lei n. ${ }^{\circ} 216$ nada teria de ofensivo à Carta Magna. Reproduz, na essência, o Direito Constitucional então vigente. Não necessitaria êle, para validar-se, do socorro do art. 173, III, da Constituição de 1967. Seria, aliás, incom- 
preensível extravagância do legislador a adoção de meio impróprio ao seu fim. Tinha a União o recurso, se não estivesse influenciada pela doutrina de ser o processo de emenda das Constituições locais a emanação de princípio federal, do Ato Complementar, que alterou ou determinou modificações, diversas vêzes, nas Cartas dos Estados (Conf. ns. 12, 14, 15, 18, 19, 24, 27, 28, 31, 33, 34 e 37). Se é válido o Decreto-lei n. ${ }^{\circ} 216$, não há porque discernir entre as prescrições adaptatórias, incorporadas por seu intermédio nos textos locais. Discriminar entre umas e outras importaria em dar conteúdo diverso, ontològicamente, ao poder constituinte e ao poder de reforma, e subdividir, sem texto constitucional, o poder constituinte de reforma sujeito a prazo do sem prazo como sêres diversos. Ora, só existe a possibilidade de distinguir entre poder constituinte e poder constituinte de reforma em virtude de regras expressas, autônomas ou heterônomas, sem que isso leve a uma diversidade ontológica, mas apenas a uma graduação (J. NARBICH - Der Bundesstaat und seine Unantastbarkeit, Berlim, 1965, pág. 92). Dar conteúdo diverso ao poder constituinte de reforma ordinária e poder constituinte de reforma especial, sem amparo na norma constitucional, com base em artificiosas interferências e conjecturas, é tese que a ninguém ocorreu, com fundamento no direito positivo ou na doutrina. Se é válido o Decreto-lei n. 216 (ou foi validado), não há porque discernir entre prescrições adaptatórias e não adaptatórias. O art. $10^{\circ}$ diz expressamente que a reforma das Constituições dos Estados "consiste primordialmente (e não exclusivamente) na modificação do respectivo texto, no que, implícita ou explìcitamente, tiver sido alterado ou fôr incompatível com as disposições constitucionais federais".

Suprima-se, entretanto, por inconstitucional o Decreto-lei n. ${ }^{\circ} 216$ e mantenha-se, para argumentar, o princípio federal do processo de emenda às Cartas Estaduais (A.I. n. ${ }^{\circ}$ 2). Sobraria o mesmo processo adotado pelo Decreto-lei n. ${ }^{\circ} 216$, com o conteúdo regimental que the dessem as Assembléias Legislativas, com os critérios inferna corporis ditados por motivos de conveniência. Ainda aí não haveria nenhuma razão para separar, sem qualquer momento, as emendas constitucionais provocadas obrigatòriamente pela alteração da Carta Federal e aquelas inspiradas no interêsse do Estado. O processo, em um e outro caso, não seria diferente, nem se encontraria apoio para fundamentar tratamento especial a cada hipótese. As emendas seriam formalmente válidas - sòmente por vício de inconstitucionalidade material poderiam ser invalidadas. Apenas a Constituição Estadual mas aí a Representação não poderia incidir -, consagrando específicas normas regimentais, poderia estabelecer trâmites diversos, como, 
sob o regime de 1946, dispuseram as Constituições da Bahia (uma só sessão legislativa, uma discussão e maioria absoluta - art: 26 $\S 3 .^{\circ}$ ) e da Guanabara (art. $8 .^{\circ}, \S 3 .^{\circ}$ - iniciativa da Mesa da Assembléia Legislativa).

Conclui-se que, sob o prisma da projeção do princípio constitucional federal sôbre o processo de reforma das Cartas Estaduais, a Representação não poderá ser acolhida, por improcedente. A tese do excesso de adaptação revela-se, em todos seus aspectos, um equivoco, com funestas e perigosas conseqüências sôbre a ordem constitucional.

9. O Decreto-lei n. ${ }^{\circ} 216$, de tanto relêvo para o problema em exame, não visou ao efeito principal de traçar normas processuais ao legislador constituinte estadual. Seu escôpo parece ter sido outro e diverso: dotar os Estados com o efeito suspensivo da Representação, se intentada dentro em sessenta dias. Legislou sôbre direito processual, matéria de competência da União.

Na parte em que sugeriu às Assembléias Legislativas as normas para efetuar a adaptação à Carta de 1967 das Constituições locais, não passou de pré-regimento. Assim o entendeu o Legislador constituinte da Guanabara, que o validou internamente por meio da Resolução n. ${ }^{\circ}$ 253, de 26 de abril de 1967 ("Diário da Assembléia Legislativa", de 28 de abril de 1967). O Decreto-lei dissolveu-se na regra regimental.

O debate em tôrno do processo adotado pelo legislador constituinte local, além de não ser objeto de Representação, não se irradia fora da Assembléia Legislativa. Constituiria lídima questão política (The Constitution of the United States - Prepared by the Leg. Ref. Serv., Libr. of Congress, Washington, 1964, pág. 612) ou interna corporis. O exame dos outros podêres, na palavra autorizada de um jurista, "não envolve as particularidades ou modalidades da elaboração legislativa, o processo pelo qual a Assembléia manifesta a sua vontade. Tais questões são interna corporis, isto é, da exclusiva competência da Assembléia Legislativa, que é o único juiz da regularidade formal das suas deliberações. Como a própria expressão sugere, interna corporis são tôdas as regras ou disposições interiores ao corpo legislativo, isto é, as prescrições destinadas a disciplinar - seu funcionamento, sejam elas instituídas no próprio regulamento interno ou na mesma Constiłuição" (FRANCISCO CAMPOS, ob. cit., vol. II, pág. 119. Esta é a tese predominante: CARLO SPOSITO La validità delle Legge, Milano, 1964, pág. 209; TJSP, Rev. de Dir. Adm., vol. 56, pág. 272; TJSP, Rev. de Dir. Adm., vol. 61, pág. 208; STF, Repr. n. ${ }^{\circ} 709$, Rev. Trim. de Jurisp., vol. 42, pág. 279). 
10. Em sumário:

a) A tese do excesso de adaptação não tem amparo no art. 188 da Constituição Federal, nem decorre do sistema constitucional da União. Ao contrário, o art. 188 supõe o poder constituinte estadual (art. 18), em tôda sua amplitude e extensão.

b) A tese do excesso de adaptação, ao desabrigo de apoio constitucional, estrutura-se na peculiaridade do processo de reforma das Cartas Estaduais, determinado pelo Decreto-lei n. ${ }^{\circ} 216$, de 27 de fevereiro de 1967, que teria ferido as disposições de emenda, previstas nas Constituições locais.

A doutrina esgalha-se em duas alternativas:

a) O processo de reforma das Cartas Estaduais obedece a princípios próprios, de livre criação dos Estados (tradição das Constituições até 1946 - a Constituição de 1967 quebrou essa continuidade, mas o ditame desta é precisamente um dos pontos de adaptação, válido 60 dias após sua vigência);

b) O processo de reforma das Constituições Estaduais é um dos princípios constitucionais da União, que informa aquelas;

c) No primeiro caso - autonomia estadual do processo de reforma constitucional -, a tese do excesso de adaptação denuncia agressão à Constituição Estadual. Contra êsse desvio não cabe a Representação, que cuida ùnicamente dos conflitos de atos normativos ou leis federais e estaduais com dispositivos da Constituição Federal;

d) No segundo caso - a reforma da Carta Estadual, por via do Decreto-lei n. ${ }^{\circ}$ 216, afrontou um princípio constitucional da União -, o argumento descansa em êrro grosseiro. A norma federal questionada não é a Constituição de 1946 (art. 217), mas o direito vigente à época da adaptação, ○ Ato Institucional n. ${ }^{\circ}$ 2. Ora, as normas de reforma constitucional neste estabelecidas são as mesmas, em tôda a latitude formal, do Decreto-lei n. ${ }^{\circ} 216$, que não padece de nenhuma inconstitucionalidade. Incompatíveis, o Decreto-lei n. 216 se converteria, por não apreciável judiciàriamente, em norma constitucional;

e) As eventuais disocrdâncias do Decreto-lei n. ${ }^{\circ} 216 \mathrm{com}$ o A.I. n. 2 são meramente regimentais, interna corporis, sôbre as quais não se estende o contrôle dos Podêres Judiciário e Executivo. O direito prevalecente considerâ tôda a matéria argüida como interna corporis, sobretudo se ponderado que o Decreto-lei n. 216 tem o caráter de esbôço ou sugestão regimental, dissolvendo-se, na Guanabara, em ato interno da Assembléia Legislativa. 